\title{
Insecticidal Activity of Pyrethroids Containing a Heterocycle against Musca domestica and Their Structure-Activity Relationship
}

\author{
Tadashi Ohsumi, Chiyozo Takayama, Takao Motoki, \\ Toshihiko Yano, Masachika Hirano and Nobushige Itaya \\ Pesticides Research Laboratory, Takarazuka Research Center, \\ Sumitomo Chemical Co., Ltd., Takatsukasa, Takarazuka 665, Japan
}

(Received March 16, 1987)

\begin{abstract}
Various kinds of pyrethroids containing a heterocycle in their alcohol moiety were synthesized and their insecticidal activity against Musca domestica, the housefly was determined by the filter paper contact method. The activity was greatly influenced by the kinds of heterocycles introduced in the alcohol moiety. The stable conformations of these pyrethroids were calculated by the MNDO molecular orbital method and their steric resemblance was studied in the stable conformations. The hydrophobicity of these pyrethroids was also measured by reversed phase HPLC and expressed in terms of $\log k^{\prime}\left[=\log \left(t_{\mathrm{R}}-t_{0}\right) / t_{0}, t_{\mathrm{R}}\right.$ : retention time of the trans isomer of the test compound, $t_{0}$ : retention time of formamide]. The analysis of the structure-activity relationship by the use of physicochemical parameters and regression analysis showed the importance of molecular shape and hydrophobicity to the insecticidal activity.
\end{abstract}

\section{INTRODUCTION}

Our previous paper ${ }^{1)}$ reported that 3-benzylpyrrol-1-ylmethyl 2,2-dimethyl-3-(2,2-dichlorovinyl)cyclopropanecarboxylate (II) was a potent insecticide, being two times as active as resmethrin $^{2)}$ against Musca domestica, the housefly. The discovery of the new pyrethroid having a pyrrole ring in the alcohol moiety led us to synthesize a series of pyrethroids containing a pyrazole, oxazole or thiazole ring instead of a pyrrole ring and to find that their insecticidal activity was greatly influenced by the kinds of heterocycles and their bonding positions.

Since pyrethroids are a class of insecticides in which the whole molecular shape is crucial for the insecticidal activity, our interest was in examining whether or not the pyrethroids with various kinds of heterocycles in the alcohol moiety could have the same molecular shape.

Tosi et al. ${ }^{3)}$ showed that fitness to a receptor is closely associated with conformational stability. This finding prompted us to calculate the stable conformation for these pyrethroids by the MNDO molecular orbital method ${ }^{4,5)}$ and to examine their steric resemblance in stable conformations.

Here we would like to report on the relationship between chemical structure and insecticidal activity by means of physicochemical parameters and regression analysis.

\section{MATERIALS AND METHODS}

\section{Syntheses of Compounds}

Compounds I-VII were prepared by reaction of 2,2-dimethyl-3-(2,2-dichlorovinyl)cyclopropanecarbonyl chloride with appropriate alcohols by the conventional method. 2-Benzyl4-furylmethanol was prepared according to the method $^{2)}$ previously described. 2-Benzyloxazole-4-methanol and 5-benzyloxazole-2-methanol were obtained by sodium borohydride reduction of 2-benzyloxazole-4-carboxalde- 
hyde $^{6)}$ and ethyl 5-benzyloxazole-2-carboxylate, $^{7,8)}$ respectively. 1-Benzylpyrazole-3methanol was synthesized by benzylation of ethyl pyrazole-3-carboxylate, ${ }^{9)}$ followed by lithium aluminum hydride reduction.

\section{4-Benzylthiazole-2-methanol}

2-Hydroxythioacetamide tetrahydropyranyl ether $(3.50 \mathrm{~g}, 0.02 \mathrm{~mol})$ and 1-bromo-3-phenyl2 -propanone ${ }^{10)}(4.26 \mathrm{~g}, 0.02 \mathrm{~mol})$ were dissolved in tetrahydrofuran with stirring overnight at room temperature. Precipitated salt was filtered and dissolved in dimethylformamide. Anhydrous potassium carbonate $(2.76$ $\mathrm{g}, 0.02 \mathrm{~mol}$ ) was added to the resulting solution and the mixture was stirred at $140^{\circ} \mathrm{C}$ for $4 \mathrm{hr}$. The reaction mixture was poured into water and extracted with ethyl acetate. After evaporating the solvent, the residue was dissolved in methanol containing a few drops of concentrated hydrochloric acid. The resulting solution was mixed with water and extracted with ethyl acetate. The extracts were concentrated and purified with column chromatography (silica gel, $n$-hexane: ethyl acetate $=1: 1, \mathrm{v} / \mathrm{v}$ ) to give $2.72 \mathrm{~g}$ of the alcohol.

The structure of the compounds was confirmed by PMR spectroscopy and their isomer ratios were determined by reversed phase high performance liquid chromatographic analysis in the same condition as described in 3.1. The prepared pyrethroids are listed below with their physical data.

2-Benzyl-4-furylmethyl 2,2-dimethyl-3-(2,2dichlorovinyl)cyclopropanecarboxylate $(\boldsymbol{I})$ PMR $\left(\mathrm{CDCl}_{3}\right) \delta \mathrm{ppm}: 7.17(1 \mathrm{H}, \mathrm{s}), 7.07(5 \mathrm{H}, \mathrm{s}), 5.86$ $(1 \mathrm{H}, \mathrm{s}), 6.12,5.47$ (1 H in total, doublet in each, $J=8.0,8.0 \mathrm{~Hz}), 4.78(2 \mathrm{H}, \mathrm{s}), 3.86(2 \mathrm{H}, \mathrm{s})$, 2.3-1.5 $(2 \mathrm{H}, \mathrm{m}), 1.4-1.1(6 \mathrm{H}, \mathrm{m})$. cis/trans $=$ $43 / 57$.

3-Benzylpyrrol-1-ylmethyl 2,2-dimethyl-3(2,2-dichlorovinyl)cyclopropanecarboxylate (II) $\operatorname{PMR}\left(\mathrm{CDCl}_{3}\right) \delta \mathrm{ppm}: 7.03(5 \mathrm{H}, \mathrm{s}), 6.7-6.5(1 \mathrm{H}$, $\mathrm{m}), 6.4-6.3(1 \mathrm{H}, \mathrm{m}), 6.0-5.8(1 \mathrm{H}, \mathrm{m}), 6.08$, $5.47(1 \mathrm{H}$ in total, doublet in each, $J=8.0,8.0$ $\mathrm{Hz}), 5.58(2 \mathrm{H}, \mathrm{s}), 3.69(2 \mathrm{H}, \mathrm{s}), 2.4-1.4(2 \mathrm{H}$, $\mathrm{m}), 1.4-1.0(6 \mathrm{H}, \mathrm{m}) . \quad n_{\mathrm{D}}^{24.5}=1.5533$. cis/trans $=$ $45 / 55$.

2-Benzyloxazol-4-ylmethyl 2,2-dimethyl-3(2,2-dichlorovinyl)cyclopropanecarboxylate (III) $\operatorname{PMR}\left(\mathrm{CDCl}_{3}\right) \delta \mathrm{ppm}: 7.36(1 \mathrm{H}, \mathrm{s}), 7.11(5 \mathrm{H}, \mathrm{s})$, $6.12,5.47(1 \mathrm{H}$ in total, doublet in each, $J=$
8.0, 8.6 Hz), 4.87 (2 H, s), 3.99 (2 H, s), 2.3-1.5

$(2 \mathrm{H}, \mathrm{m}), 1.4-1.0(6 \mathrm{H}, \mathrm{m}) . \quad n_{\mathrm{D}}^{16.0}=1.5340 . \quad$ cis/ trans $=43 / 57$.

1-Benzylpyrazol-4-ylmethyl 2, 2-dimethyl-3(2,2-dichlorovinyl)cyclopropanecarboxylate $(\boldsymbol{I} \boldsymbol{V})$ $\mathrm{PMR}\left(\mathrm{CDCl}_{3}\right) \delta \mathrm{ppm}: 7.29(1 \mathrm{H}, \mathrm{s}), 7.18(1 \mathrm{H}$, s), 7.4-6.9 $(5 \mathrm{H}, \mathrm{m}), 6.2-5.4(1 \mathrm{H}$ in total, doublet in each, $J=8.0,8.0 \mathrm{~Hz}), 5.3(2 \mathrm{H}, \mathrm{s})$, $4.83(2 \mathrm{H}, \mathrm{s}), 2.4-1.4(2 \mathrm{H}, \mathrm{m}), 1.4-1.1(6 \mathrm{H}$, $\mathrm{m}) . n_{\mathrm{D}}^{27.0}=1.5503$. cis $/$ trans $=43 / 57$.

4-Benzylthiazol-2-ylmethyl 2, 2-dimethyl-3(2,2-dichlorovinyl)cyclopropanecarboxylate $(\boldsymbol{V})$ $\operatorname{PMR}\left(\mathrm{CDCl}_{3}\right) \delta \mathrm{ppm}: 7.08(5 \mathrm{H}, \mathrm{s}), 6.58(1 \mathrm{H}$, $\mathrm{s}), 6.12,5.48(1 \mathrm{H}$ in total, doublet in each, $J=7.8,8.0 \mathrm{~Hz}), \quad 5.20(2 \mathrm{H}, \mathrm{s}), 3.98(2 \mathrm{H}, \mathrm{s})$, 2.4-1.5 $(2 \mathrm{H}, \mathrm{m}), \quad 1.5-1.1 \quad(6 \mathrm{H}, \mathrm{m}) . \quad n_{\mathrm{D}}^{20.0}=$ 1.5641. cis/trans $=40 / 60$.

1-Benzylpyrazol-3-ylmethyl 2,2-dimethyl-3(2, 2-dichlorovinyl)cyclopropanecarboxylate (VI) $\operatorname{PMR}\left(\mathrm{CDCl}_{3}\right) \quad \delta \mathrm{ppm}: \quad 7.4-6.9 \quad(6 \mathrm{H}, \mathrm{m}), 6.11$ $(1 \mathrm{H}, \mathrm{d}, J=2.4 \mathrm{~Hz}), 6.21,5.47$ ( $1 \mathrm{H}$ in total, doublet in each, $J=8.4,8.4 \mathrm{~Hz}), 5.10(2 \mathrm{H}, \mathrm{s})$, $4.98(2 \mathrm{H}, \mathrm{s}), 2.5-1.5(2 \mathrm{H}, \mathrm{m}), \quad 1.4-1.0(6 \mathrm{H}$, $\mathrm{m}) . n_{\mathrm{D}}^{19.5}=1.5561$. cis/trans $=44 / 56$.

5-Benzyloxazol-2-ylmethyl 2,2-dimethyl-3(2,2-dichlorovinyl)cyclopropanecarboxylate (VII) PMR $\left(\mathrm{CDCl}_{3}\right) \delta \mathrm{ppm}: 7.09(5 \mathrm{H}, \mathrm{s}), 6.50(1 \mathrm{H}$, $\mathrm{s}), 6.11,5.46(1 \mathrm{H}$ in total, doublet in each, $J=$ 8.0, $8.0 \mathrm{~Hz}), 4.93(2 \mathrm{H}, \mathrm{s}), 3.88(2 \mathrm{H}, \mathrm{s}), 2.4$ $1.5(2 \mathrm{H}, \mathrm{m}), \quad 1.4-1.0(6 \mathrm{H}, \mathrm{m}) . \quad n_{\mathrm{D}}^{31.0}=1.5440$. cis $/$ trans $=40 / 60$.

\section{Biological Activity}

Ten milligrams of the test compound (isomeric mixture) was dissolved in $0.1 \mathrm{ml}$ of xylene-dimethylformamide $(1: 1 \mathrm{v} / \mathrm{v})$ containing Sorpol 3005X (35 mg). The resulting solution was added to deionized water to give an aqueous solution of predetermined concentration. The solution $(0.7 \mathrm{ml})$ was dropped on the filter paper $(5.5 \mathrm{~cm}$ in diameter) placed in a plastic cup with sucrose $(30 \mathrm{mg})$. Ten female adult houseflies were released in the plastic cup and their mortality was assessed $48 \mathrm{hr}$ later. The insecticidal activity was expressed as the $\mathrm{pLC}_{50}$, negative logarithm of the molar concentration required for the $50 \%$ mortality.

\section{Physicochemical Parameter}

According to Burt et al. ${ }^{11)}$ (土)-trans and cis isomers of $\mathbf{I}$ are almost equal in insecticidal 
activity against $M$. domestica and their ratio is 100: 94 (=trans: cis). Since compounds IVII are isomeric mixtures having almost the same trans: cis ratio $(=3: 2)$ and the activity of trans and cis isomers in each of I-VII is supposed to be not much different from the activity of I-VII, physicochemical parameters could be calculated against the trans isomer to analyze the structure-activity correlation by Hansch-Fujita's method. ${ }^{12}$ )

\subsection{Hydrophobicity}

Hydrophobicity of compounds I-VII was measured by reversed phase high performance liquid chromatographic analysis [column: YMC Pack AM 303 (ODS S-5, $4.5 \mathrm{~mm} \times 25 \mathrm{~cm}$ ) purchased from Sumika Chemical Analysis Service Ltd., head pressure: $80 \mathrm{~kg} / \mathrm{cm}^{2}$, column temp.: $40^{\circ} \mathrm{C}$, analytical wavelength: $215 \mathrm{~nm}$, mobile phase: water-acetonitrile $(20: 80 \mathrm{v} / \mathrm{v})$, non-retained substance: formamide]. It is expressed in terms of $\log k^{\prime 13)}\left[=\log \left(t_{\mathrm{R}}-t_{0}\right) / t_{0}\right.$, $t_{\mathrm{R}}$ : retention time of the trans isomer of the test compound, $t_{0}$ : retention time of formamide].

\subsection{Steric resemblance}

In this study compound I was selected as a reference molecule to be matched with compounds II-VII because of its highest insecticidal activity. Since all compounds (I-VII) have a 2,2-dimethyl-3-(2,2-dichlorovinyl)cyclopropanecarboxyl group, this group was held in the trans form and kept fixed in the conformation based on the results of X-ray analysis ${ }^{14)}$ obtained for an allethrin derivative. The initial shapes for heterocycles of compounds I-VII were based on X-ray analysis data $^{15,16)}$ and their initial conformations for optimization were chosen using the Dreiding model to give the minimum number of contacts between nonbonded atoms. Optimization was done by the use of the MNDO method for the part of the reference molecule (I) listed in Table 1. The same part of the others was optimized for calculating their stable conformations. Steric resemblance was measured by superimposing I on the other compounds (II-VII) in stable conformations. Superimposition was done to bring the compounds as close as possible to the guidance of the reference atoms shown in Fig. 1. Root-mean-square (RMS) deviation of distances was calculated by extracting the square
Table 1 Optimization of the bond length, and bond and torsion angles of compound $\mathbf{I}$.

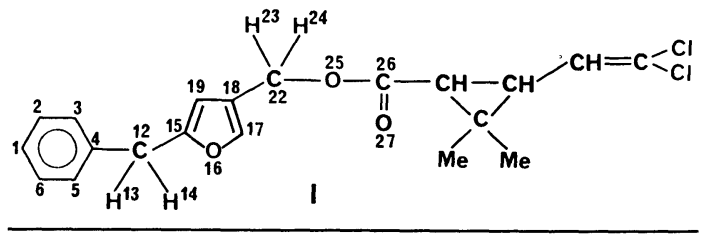

Defining atoms

\begin{tabular}{lll}
\hline Bond length & Bond angle & \multicolumn{1}{c}{ Torsion angle } \\
\hline $\mathrm{C} 4-\mathrm{C} 12$ & $\mathrm{C} 4-\mathrm{C} 12-\mathrm{H} 13$ & $\mathrm{C} 3-\mathrm{C} 4-\mathrm{C} 12-\mathrm{H} 13$ \\
$\mathrm{C} 12-\mathrm{C} 15$ & $\mathrm{C} 4-\mathrm{C} 12-\mathrm{H} 14$ & $\mathrm{C} 3-\mathrm{C} 4-\mathrm{C} 12-\mathrm{H} 14$ \\
$\mathrm{C} 15-\mathrm{O} 16$ & $\mathrm{C} 4-\mathrm{C} 12-\mathrm{C} 15$ & $\mathrm{C} 3-\mathrm{C} 4-\mathrm{C} 12-\mathrm{C} 15$ \\
$\mathrm{O} 16-\mathrm{C} 17$ & $\mathrm{C} 12-\mathrm{C} 15-\mathrm{O} 16$ & $\mathrm{C} 4-\mathrm{C} 12-\mathrm{C} 15-\mathrm{O} 16$ \\
$\mathrm{C} 17-\mathrm{C} 18$ & $\mathrm{C} 15-\mathrm{O} 16-\mathrm{C} 17$ & $\mathrm{C} 12-\mathrm{C} 15-\mathrm{O} 16-\mathrm{C} 17$ \\
$\mathrm{C} 18-\mathrm{C} 19$ & $\mathrm{O} 16-\mathrm{C} 17-\mathrm{C} 18$ & $\mathrm{C} 15-\mathrm{O} 16-\mathrm{C} 17-\mathrm{C} 18$ \\
$\mathrm{C} 17-\mathrm{H} 20$ & $\mathrm{C} 17-\mathrm{C} 18-\mathrm{C} 19$ & $\mathrm{O} 16-\mathrm{C} 17-\mathrm{C} 18-\mathrm{C} 19$ \\
$\mathrm{C} 19-\mathrm{H} 21$ & $\mathrm{O} 16-\mathrm{C} 17-\mathrm{H} 20$ & $\mathrm{C} 15-\mathrm{O} 16-\mathrm{C} 17-\mathrm{H} 20$ \\
$\mathrm{C} 18-\mathrm{C} 22$ & $\mathrm{C} 18-\mathrm{C} 19-\mathrm{H} 21$ & $\mathrm{C} 17-\mathrm{C} 18-\mathrm{C} 19-\mathrm{H} 21$ \\
$\mathrm{C} 22-\mathrm{H} 23$ & $\mathrm{C} 17-\mathrm{C} 18-\mathrm{C} 22$ & $\mathrm{O} 16-\mathrm{C} 17-\mathrm{C} 18-\mathrm{C} 22$ \\
$\mathrm{C} 22-\mathrm{H} 24$ & $\mathrm{C} 18-\mathrm{C} 22-\mathrm{H} 23$ & $\mathrm{C} 17-\mathrm{C} 18-\mathrm{C} 22-\mathrm{H} 23$ \\
$\mathrm{C} 22-\mathrm{O} 25$ & $\mathrm{C} 18-\mathrm{C} 22-\mathrm{H} 24$ & $\mathrm{C} 17-\mathrm{C} 18-\mathrm{C} 22-\mathrm{H} 24$ \\
& $\mathrm{C} 18-\mathrm{C} 22-\mathrm{O} 25$ & $\mathrm{C} 17-\mathrm{C} 18-\mathrm{C} 22-\mathrm{O} 25$ \\
\hline
\end{tabular}

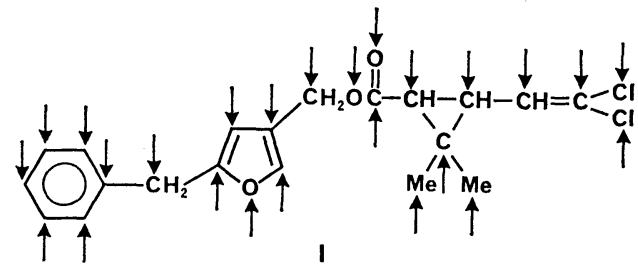

Fig. 1 The reference molecule for superimposition.

Reference atoms for matching are denoted by arrows.

root of mean from the square of the interatomic distances in the matched features. Steric resemblance was expressed by the RMS value.

All computation was done on an $\mathrm{ACACS}^{17)}$ (Advanced Computer-Aided Chemistry System) developed by Sumitomo Chemical Co., Ltd., Sumitomo Pharmaceuticals Co., Ltd. and NEC Co., Ltd.

\section{RESULTS AND DISCUSSION}

RMS and $\log k^{\prime}$ values of compounds I-VII are listed in Table 2 with their insecticidal 
Table 2 Physicochemical parameters of compounds I-VII and their insecticidal activity against $M$. domestica.

\begin{tabular}{|c|c|c|c|c|}
\hline Compd. & Structure & $\begin{array}{l}\text { RMS value } \\
\qquad(\AA)\end{array}$ & $\log k^{\prime}$ & $\begin{array}{l}\text { M. domestica } \\
\mathrm{pLC}_{50}\end{array}$ \\
\hline I & & 0.00 & 0.38 & 5.10 \\
\hline II & & 0.16 & 0.36 & 5.10 \\
\hline III & & 0.15 & 0.07 & 4.32 \\
\hline IV & & 0.15 & -0.01 & 3.93 \\
\hline $\mathbf{v}$ & & 0.36 & 0.26 & 3.52 \\
\hline VI & & 0.29 & 0.03 & 3.46 \\
\hline VII & & 0.62 & -0.07 & 3.32 \\
\hline
\end{tabular}

activity, $\mathrm{pLC}_{50}$. The examination on the relationship between the RMS and $\mathrm{pLC}_{50}$ values produced Eq. (1).

$$
\begin{gathered}
\mathrm{pLC}_{50}=-3.007 \mathrm{RMS}+4.850 \\
\quad(2.687) \quad(0.827) \\
n=7, s=0.508, r=0.790, F_{1,5}=8.3
\end{gathered}
$$

In this and the following equations, $n$ is the number of data points used in the correlation, $s$ the standard deviation, $r$ the correlation coefficient, $F_{\nu_{1} \nu_{2}}$ the $F$-value of the correlation $\left(\nu_{1}=m\right.$ and $\nu_{2}=n-m-1 ; m$ is the number of independent variables used in the correlation) and the figures in parentheses the 95\% confidence limits. Parameter terms and intercept are justified at levels between 97.5 and $95 \%$ and above $99.5 \%$ by the $t$-test respectively. Equation (1) indicates that the compounds with the three-dimensional structure similar to the reference molecule are expected to have high insecticidal activity, which is in good accordance with the empirical knowledge that the whole molecular shape plays a very im- portant role for the insecticidal activity of pyrethroids.

Recent studies ${ }^{18,19)}$ on structure-activity relationships of pyrethroids have shown that their insecticidal activity is closely related to their hydrophobicity. In our study on the relationship between the hydrophobicity and insecticidal activity of I-VII, Eq. (2) also shows that the hydrophobicity determines the insecticidal activity. The insecticidal activity increases with the hydrophobicity of compounds.

$$
\begin{gathered}
\mathrm{pLC}_{50}=3.160 \log k^{\prime}+3.650 \\
(3.055) \quad(0.681) \\
n=7, s=0.533, r=0.765, F_{1,5}=7.1
\end{gathered}
$$

Since the squared correlation coefficient between the $\log k^{\prime}$ and RMS is rather small (0.325), they could be taken as independent parameters. The coefficients of the $\log k^{\prime}$ and RMS terms in the equations are nearly the same with a different sign. The $\mathrm{pLC}_{50}$ values of $\mathbf{I}-$ VII were plotted against ( $\left.\log k^{\prime}-\mathrm{RMS}\right)$ values 


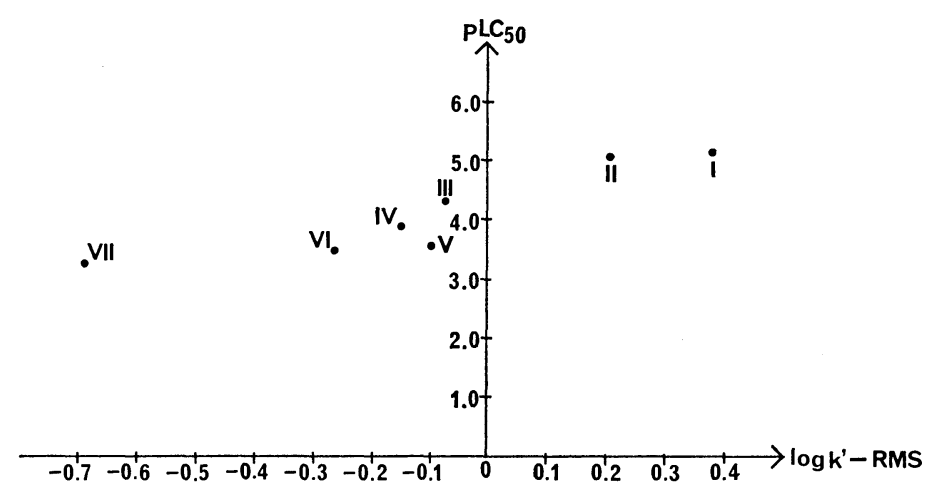

Fig. 2 The relationship between insecticidal activity and $\log k^{\prime}-$ RMS values.

to give Fig. 2, which indicates that the activity is linearly related to the $\log k^{\prime}-\mathrm{RMS}$ value.

It is noteworthy that $\log k^{\prime}$ and RMS values could be adopted to the analysis of structureactivity correlation of pyrethroids with various kinds of heterocycles in the alcohol moiety. The insecticidal activity of structural isomers (III and VII, IV and VI) with the same heterocycle in the alcohol moiety could be conveniently analyzed by this regression analysis technique.

The reason why compound II was most active among compounds II-VII is that it has not only the structure similar to the reference molecule (I) but also higher hydrophobicity than the others (III-VII).

The above findings provide the conclusion that both the molecular shape and hydrophobicity are the two factors which must be taken into consideration in order to design new pyrethroids efficiently.

\section{ACKNOWLEDGMENTS}

We wish to express our thanks to Prof. T. Fujita of Kyoto University for his valuable advice.

\section{REFERENCES}

1) T. Ohsumi, M. Hirano, N. Itaya \& Y. Fujita: Pestic. Sci. 12, 53 (1981)

2) M. Elliott, A. W. Farnham, N. F. Janes, P. H. Needham \& B. C. Pearson: Nature (London) 213, 493 (1967)

3) C. Tosi, L. Barino, G. Castellani \& R. Scordamaglia: J. Mol. Struc. 87, 315 (1982)

4) M. J. S. Dewer \& W. Thiel: J. Am. Chem. Soc.
99, 4899 (1977)

5) M. J. S. Dewer \& W. Thiel: J. Am. Chem. Soc. 99, 4907 (1977)

6) J. W. Cornforth, E. Fawaz, L. J. Goldsworthy \& Sir R. Robinson: J. Chem. Soc. 1949, 1549

7) C. Tanaka \& H. Shibakawa: Yakugaku-zasshi 91, 425 (1971)

8) T. Saito \& C. Tanaka: Yakugaku-zasshi 76, 305 (1956)

9) R. G. Jones: J. Am. Chem. Soc. 71, 3994 (1949)

10) R. H. Good \& G. Jones: J. Chem. Soc. (C) 1970, 1938

11) P. E. Burt, M. Elliott, A. W. Farnham, N. F. Janes, P. H. Needham \& D. A. Pulman: Pestic. Sci. 5, 791 (1974)

12) C. Hansch \& T. Fujita: J. Am. Chem. Soc. 86, 1616 (1964)

13) K. Miyake, N. Mizuno \& H. Terada: Chem. Pharm. Bull. 34, 4787 (1986)

14) M. J. Begley, L. Crombie, D. J. Simmonds \& D. A. Whiting: J. Chem. Soc. Perkin 1 1974, 1230

15) Cambridge Crystallographic Database, Crystallographic Data Center, University Chemical Laboratory, Cambridge, England

16) Nihon Kagakukai: Kagaku-binran (Part II), Maruzen Press, Tokyo, 1966

17) M. Yoshida, C. Takayama, S. Morooka \& A. Yokota: Abstr. 7th Int. Conf. Comput. Chem. Res. Educ., Garmisch-Partenkirchen (Federal Republic of Germany), Poster No. 32, 1985

18) K. Nishimura, N. Okajima, T. Fujita \& M. Nakajima: Pestic. Biochem. Physiol. 18, 341 (1982)

19) M. Hatakoshi, N. Matsuo, I. Nakayama, O. Kirino \& C. Takayama: J. Pestic. Sci. 9, 659 (1984) 
要 約

イエバエに対する含複素環ピレスロイドの殺虫 活性およびその構造活性相関

大住忠司, 高山千代蔵, 本木隆夫, 矢野俊彦 平野雅親, 板谷信重 種々のへテロ環をアルコール成分に有するピレスロイ ドを合成し，イエバエに対する殺虫活性を測定した。そ の結果, 活性は, 導入されるへテロ環の種類に著しく影
響を受けることが明らかとなった。これらピレスロイド の安定コンフォメーションを MNDO 法を用いて計算 し，2-ベンジル-4-フリルメチル 2,2-ジメチル-3- 2 -2ジクロロビニル)シクロプロパンカルボキシレートを対 照分子として立体類似性（RMS 值）を算出した。 RMS 值および逆相液体クロマトグラフィーを用いて測定した $\log k^{\prime}$ 值は殺虫活性と相関性を示し, ピレスロイドの殺 虫活性における立体形状と疎水性の重要性が示唆され た. 